\title{
Partitioning of Accumulated Dry Matter Along the Seed Fill Duration of some Wheat Varieties (Triticumaestivuml.)
}

\author{
Aram MOHAMMED ${ }^{1 *}$, Sazan JAZA ${ }^{2}$ \\ ${ }^{1}$ Faculty of Agricultural sciences, University of Sulaimani, KRG Iraq \\ ${ }^{2}$ Sulaimani Crop Research Center- Bakrajo, Sulaimani, KRG Iraq \\ *Corresponding author: aram.muhammed@univsul.edu.iq
}

Bulletin USAMV series Agriculture 72(2)/2015

Print ISSN 1843-5246; Electronic ISSN 1843-5386

DOI 10.15835/buasvmcn-agr: 11729

\begin{abstract}
Seven wheat varieties were cultivated during the winter seasons of 2013 and 2014 in Sulaimani Crop Research Center - Bakrajo. A Field experiment was conducted each year as CRBD with three replications.The most important vegetative and reproductive criteria were studied as well as dry matter accumulation and its partitioing through destructive samples. They were taken every 10 days in order to study the partitioning of assimilates to different parts of the plant leaf, stem, and spike under different environmental factors of the two years.The influence of the duration length of seed filling on the accumulated dry matter and its partitioning to the spike, the Spike Partitioning Coefficient and growth parameters such as Seed Growth Rate (SGR) and Seed Filling Duration (SFD)were studied. Environmental factors were influenced the Dry matter accumulation and the partitioning of assimilates as well as the length of the growth stages especially SFD.
\end{abstract}

Keywords: DM accumulation, partioning, SFD,SGR, Wheat varietes.

\section{INTRODUCTION}

Wheat(Triticum aestivum L.) is considered as a widely adapted crop, it is grown in different environments with various environmental stresses, particularly heat and water deficit that may shorten or lengthenen the wheat growth between phases. Thus final yield is therefore the product of cumulative seasonal biotic and abiotic factors (FAO, 2015) . In most seed crops, individual seed weight is commonly analysed as the product of the individual seed growth rate by the duration of seed filling (Munier-Jolain, et al. 1998).The environmental conditions and there is genetic variation in most crops, Seed-fill duration in many crops increases as temperature decreases below $30^{\circ} \mathrm{C}$. Water stress during the seed filling accelerates leaf senescence and shortens the seed filling period. The response of seed-fill duration to alterations in source-sink ratios is inconsistent.
It probably depends on whether the supply of assimilate to the seed is affected and if the seed can respond to changes in assimilation supply. Stem reserves offer a powerful resource for grain filling under any type of stress which inhibits current assimilation that can be supply by photosynthesis (Blum, 1998; Egli, 2004).

Accumulated dry matter varies according to wheat growth stages and the environmental factors that will exceed during the growth stages along the life-cycle from emergence to physiological maturity. Environmental factors could effect dry matter accumulation and its partitioning through the effect on the energy balance between photosynthesis and respiration. Temperature is one of the main driving forces for wheat growth and development. Several phonological stages are manifested throughout its development, high temperature could affect SGR directly by affecting 
seed metabolism or by affecting the supply of assimilate to the seeds (Egli, 1998). Total dry matter accumulation was adversely affected by heat stress and reduces the dry matter production (Nicolas etal., 1984; Sanghera and Thind 2014). Dry matter accumulation and cell division proceeded at a higher rate but had a shorter duration of the high temperature treatments (Nicolas et al., 1984). The dry matter partitioned to stem and Spike, in particular, responded quantitatively in different manners to changes in environmental resources, and provided insights into how single plants interact with their environment, adjust their dry matter partitioning, and determine grain yield (Jaradat, 2009).

\section{MATERIALS AND METHODS}

Seven wheat varieties included Aras local variety and six foreign varieties were cultivated in the winter season of 2013 November and repeated in winter 2014. Field experiment was conducted in both years by CRBD with three replications at the Sulaimani Research Center- Bakrajo. All agricultural processes were practiced as required. Vegetative criteria such as length of growth season, within growth stages and reproductive criteria, 1000 grain weight, biological weight, grain yield, and Harvest index were studied as well as the rate of dry matter accumulation and its partitioning to plant parts stem, leaves and spike each every 10 days (from anthesis) were determined in order to study the Seed Growth rate (SGR) with an equation:

$\mathrm{SGR}=\ln \mathrm{W}_{2}-\ln \mathrm{W}_{1} / \mathrm{t}_{2}-\mathrm{t}_{1}$

Where: $\ln W_{2}$ is natural logrithm of weight number

2 of the sample.
Ln $\mathrm{W}_{1}$ is natural logrithm of weight number 1 of the sample.

$\mathrm{t}_{2}$ is the time (number of days 2.)

$\mathrm{t}_{1}$ is the time (number of days 1.)

In order to study the effect of seed filling duration (SFD) on the biomass and yield increasing and the effect of partitioning to the spike, the parameter Spike partitioning coefficient (SPC) was estimated according to the following relations (Donaldson, 1999 cited by Kumar et al., 2006):

SPC $\%=S D W / D M T \times 100$

\section{Where SDW-spike dry weight}

DMT-amount of dry matter translocated

\section{RESULTS AND DISCUSSIONS Vegetative Growth Characters}

Tab. 1 reveals significant differences among some of studied vegetative traits of the seven wheat varieties in the first season, while there were no significant differences among varieties due to number of days of filling period. However significant differences were recorded between the length of growth stages no. of days to $50 \%$ heading, no. of days to $50 \%$ flowering, and no. of days to $50 \%$ maturity in which the local variety (Aras)as an adapted cultivar showed minimum durations for the three stages by $(123.333,128.000$, and 167.000) days, respectively.

Tab. 1, indicates to significant differences in the required days to maturity which was between (170 to 171.666) days of the six foreign varieties with only 1.666 day difference, while the local variety (Aras)needed 167 days as well as the intervals between the different growth stages of the local variety was shortest than other

Tab. 1. Vegetative growth traits studied in the $1^{\text {st }}$ year

\begin{tabular}{cccccccc}
\hline Varieties & $\begin{array}{c}\text { No } \\
\text { of leaves }\end{array}$ & $\begin{array}{c}\text { Plant height } \\
\text { (cm) }\end{array}$ & No of tillering & $\begin{array}{c}\text { No. of days to } \\
50 \% \text { heading }\end{array}$ & $\begin{array}{c}\text { No. of days } \\
\text { to 50\% } \\
\text { flowering }\end{array}$ & $\begin{array}{c}\text { No. of days } \\
\text { to 50\% } \\
\text { maturity }\end{array}$ & $\begin{array}{c}\text { Filling } \\
\text { period (day) }\end{array}$ \\
\hline D30 & 4.500 & 76.000 & 3.666 & 124.000 & 129.666 & 170.000 & 40.334 \\
\hline D31 & 5.000 & 84.666 & 3.666 & 127.333 & 131.333 & 171.333 & 40.000 \\
\hline Ayorio & 4.166 & 67.666 & 3.333 & 131.333 & 130.666 & 171.667 & 41.001 \\
\hline Addna99 & 5.000 & 78.666 & 3.000 & 126.333 & 131.000 & 171.333 & 40.333 \\
\hline Azar & 4.333 & 112.666 & 4.000 & 127.333 & 132.000 & 171.667 & 39.667 \\
\hline Cehan99 & 5.333 & 79.333 & 3.666 & 128.000 & 131.666 & 171.667 & 40.001 \\
\hline Aras & 4.766 & 83.000 & 3.333 & 123.333 & 128.888 & 167.000 & 39.000 \\
\hline LSD & N.S & $6.172 *$ & N.S & $1.267 *$ & $3.823^{*}$ & $1.326^{*}$ & NS \\
\hline
\end{tabular}


varieties that might be due to its adaptation (Liu et al.,2010).There was similar result for SFD, in which there were not significant differences among all varieties. According to the previous results the differences between varieties in the reproductive criteria should be sourced from the partitioning of dry matter accumulated during the life-cycle of the wheat varieties (Salazar-Gutierrez et al., 2013).

Tab. 2 reveals the response of wheat varieties to environmental factors of the second season, in which there were significant differences among wheat varieties in vegetative growth criteria except no. of leaves. The local variety Aras showed similar result of first season that required minimum days required to $50 \%$ heading, $50 \%$ flowering, and $50 \%$ maturity with $(136.666,141$, and 171$)$ days respectively. In case of number of days of filling period were decreasing in the number of days was realized for all varieties in this season (climatic factors might affect the decrease in filling period, appendix 2), and the Azar variety exceeded others by 37.333 days, while D30 variety passed the stage with minimum days of 33.333 days. The results agree with what were investigated by (Egli, 2004; FAO, 2015).

\section{Reproductive Criteria}

Tab. 3 indicates significant differences among seven wheat varieties responses to reproductive criteria in first season. Variety D31 exceeded other varieties in the criteria of yield, Biological Yield, and HI giving (3491.667 $\mathrm{kgha}^{-1}, 10500 \mathrm{~kg} \mathrm{ha}^{-1}$, and 0.33 ) respectively. No significant difference in 1000 grain weight was observed between D31 and Azar varieties that recorded maximum weight by $32.533 \mathrm{~g}$. However, the minimum records of previous characters were shown by Azar, D30, Azar, and cehan99. Tab. 4, shows significant response of the seven wheat varieties to the environmental conditions for the second season in which variety D31 exceeded all variety in producing maximum yield and largest Harvest Index by $(4679.667 \mathrm{~kg}$ $\mathrm{ha}^{-1}$ and 0.323 , respectively, while the minimum

Tab.2. Vegetative growth traits studied in the $2^{\text {nd }}$ year

\begin{tabular}{cccccccc}
\hline Varieties & No of leaves & $\begin{array}{c}\text { Plant height } \\
(\mathrm{cm})\end{array}$ & $\begin{array}{c}\text { No of } \\
\text { tillering }\end{array}$ & $\begin{array}{c}\text { No. of days } \\
\text { to } 50 \% \\
\text { heading }\end{array}$ & $\begin{array}{c}\text { No. of days } \\
\text { to } 50 \% \\
\text { flowering }\end{array}$ & $\begin{array}{c}\text { No. of days } \\
\text { to } 50 \% \\
\text { maturity }\end{array}$ & $\begin{array}{c}\text { Filling } \\
\text { period (day) }\end{array}$ \\
\hline D30 & 4.500 & 92.000 & 4.000 & 139.333 & 143.666 & 177.000 & 33.333 \\
\hline D31 & 5.000 & 94.666 & 4.000 & 140.333 & 143.000 & 178.000 & 35.000 \\
\hline Ayorio & 4.166 & 78.333 & 5.000 & 143.000 & 149.000 & 183.000 & 34.000 \\
\hline Addna99 & 5.000 & 93.000 & 4.333 & 140.333 & 143.666 & 178.333 & 34.666 \\
\hline Azar & 4.333 & 115.333 & 4.333 & 140.000 & 143.666 & 181.000 & 37.333 \\
\hline Cehan99 & 5.333 & 90.000 & 3.000 & 141.000 & 143.666 & 178.666 & 35.000 \\
\hline Aras & 4.766 & 94.666 & 4.333 & 136.666 & 141.000 & 177.000 & 36.000 \\
\hline LSD & N.S & $5.289^{*}$ & $0.989^{*}$ & $0.989^{*}$ & $0.951^{*}$ & $0.896^{*}$ & $1.186^{*}$ \\
\hline
\end{tabular}

Tab. 3. Reproductive traits studied in the $1^{\text {st }}$ year

\begin{tabular}{ccccc}
\hline Varieties & Wt. of 1000 grain & Yield & kg ha $^{-1}$ Biological yield(g) & HI \\
\hline D30 & 29.133 & 3491.667 & 10500.000 & 0.33 \\
\hline D31 & 29.800 & 4144.166 & 12416.667 & 0.33 \\
\hline Ayorio & 28.266 & 3899.167 & 11833.333 & 0.32 \\
\hline Addna99 & 27.533 & 4065.833 & 12500.000 & 0.32 \\
\hline Azar & 32.533 & 3400.000 & 12000.000 & 0.28 \\
\hline Cehan99 & 27.266 & 4007.500 & 12250.000 & 0.32 \\
\hline Aras & 29.733 & 3950.000 & 11250.000 & 0.35 \\
\hline LSD & 2.986 & 472.617 & NS & 0.043 \\
\hline
\end{tabular}


yield production and the shortest $\mathrm{HI}$ were recorded by Azar variety with $\left(2248 \mathrm{~kg} \mathrm{ha}^{-1}\right.$ and 0.163 ) respectively. Although the maximum weight of 1000 grain weight was recorded by this variety but its impact on the variety final yield was not effective. It may be due to the variation in number of grains produced by varieties as another important yield component (Egli, 1998).

Dry Matter Accumulation and Partitioning

Tabs. 5,6, and 7 indicates significant differences among seven varieties in the rate of dry matter accumulation which partitioned to the leaves, stem, and spike in both seasons from April14 ${ }^{\text {th }}$, in which $50 \%$ flowering occurred, to May $25^{\text {th }}$ that all varieties were in physiological maturity stage. There was an increasing in dry matter partitioned to the spike in both seasons. However according to the result data of table 5 there were significant differences in allocating assimilates to the spike during the beginning of the seed filling period in April, There were no significant differences in the amount of DM partitioned to spike in the mid and the later weeks of seed filling period. At the beginning period of seed filling April $14^{\text {th }}$ of the first season the V1 variety exceeded others in the amount of dry matter, partitioned to spike by 2.633 g. While V4 variety recorded the smallest amount by $1.4 \mathrm{~g}$, At the mid season in which there was no significant differences among varieties there was increasing in seed Growth Rate (SGR) recorded by all varieties from the beginning of SFD to the mid of the period with variation among varieties. The maximum SGR was recorded by V2(D31) in the mid of filling period by $0.143 \mathrm{~g} \mathrm{~d}^{-1}$, while the minimum SGR was presented by $\mathrm{V} 7$ recording $0.062 \mathrm{~d}^{-1}$. The SGR from the mid of SFD to PM revealed agreat variation among seven varieties, while the V1 variety showed maximum SGR. There was declining in the SGR of the varieties V3 and V7 by 0.007 and $0.070 \mathrm{~g} \mathrm{~d}^{-1}$ respectively.This declining may be manifested because of PM of the two varieties were occurred much earlier genetically

Tab. 4. reproductive traits studied in the $2^{\text {nd }}$ year

\begin{tabular}{ccccc}
\hline Varieties & $\begin{array}{c}\text { Wt. of 1000 grain } \\
(\mathrm{g})\end{array}$ & $\begin{array}{c}\text { Yield } \\
\mathrm{kg} \mathrm{ha}^{-1}\end{array}$ & Biological yield $(\mathrm{g})$ & HI \\
\hline D30 & 26.333 & 4154.667 & 14166.67 & 0.29 \\
\hline D31 & 27.000 & 4679.667 & 14583.333 & 0.32 \\
\hline Ayorio & 25.000 & 3054.000 & 13083.33 & 0.23 \\
\hline Addna99 & 26.666 & 3990.667 & 16250.000 & 0.26 \\
\hline Azar & 32.333 & 2248.000 & 13333.333 & 0.16 \\
\hline Cehan99 & 26.666 & 3914.667 & 16083.333 & 0.24 \\
\hline Aras & 32.666 & 3443.667 & 13250.000 & 0.26 \\
\hline LSD & $2.585^{*}$ & 600.126 & 1935.777 & $0.046^{*}$ \\
\hline
\end{tabular}

Tab. 5. Dry matter accumulation partitioned to spike in both seasons

Accumulated Dry Matter Partitioned to Spike

\begin{tabular}{ccccccccccc} 
Varieties & \multicolumn{4}{c}{ First Season } & \multicolumn{5}{c}{ Second Season } \\
\cline { 2 - 12 } & $14 / 4$ & $24 / 4$ & $5 / 5$ & $15 / 5$ & $25 / 5$ & $14 / 4$ & $24 / 4$ & 5 -May & $15 / 5$ & $25 / 5$ \\
\hline V1 & 2.633 & 3.733 & 5.467 & 5.133 & 8.567 & 4.000 & 1.767 & 3.933 & 6.200 & 8.167 \\
\hline V2 & 1.667 & 2.833 & 4.667 & 5.233 & 5.567 & 4.000 & 1.067 & 5.367 & 4.700 & 2.400 \\
\hline V3 & 2.400 & 1.633 & 3.933 & 2.900 & 3.800 & 5.000 & 3.033 & 5.067 & 4.967 & 2.800 \\
\hline V4 & 1.400 & 2.800 & 3.400 & 4.867 & 4.567 & 4.333 & 1.100 & 4.567 & 5.267 & 4.667 \\
\hline V5 & 2.133 & 2.733 & 4.167 & 4.100 & 5.267 & 4.333 & 1.800 & 2.200 & 4.167 & 3.667 \\
\hline V6 & 2.300 & 2.533 & 4.667 & 4.667 & 4.833 & 3.000 & 1.067 & 3.967 & 4.300 & 3.667 \\
\hline V7 & 2.133 & 4.067 & 4.800 & 3.467 & 3.400 & 4.333 & 1.600 & 6.367 & 5.267 & 6.633 \\
\hline L.S.D & 1.685 & 2.402 & NS & NS & 3.626 & 0.989 & 1.633 & 2.244 & NS & 2.873 \\
\hline
\end{tabular}


or as response to environmental factors. The results agree with some other (Meng et al., 2013; Sanghera and Thind, 2014). Tab. 5 reveals significant differences among seven varieties in accumulating and partitioning of assimilates to spike in the second year across the SFD. Variety V3 has superiority in compare to others in April, $14^{\text {th }}$ and April 24 th . The local variety exceeded others at the mid of season by $6.367 \mathrm{~g}$, while V1 exceed all varieties at May $15^{\text {th }}$ and May $25^{\text {th }}$ by $6.2 \mathrm{~g}$ and $8.167 \mathrm{~g}$, respectively, however varieties( V6,V5,and V2) recorded the smallest amount of DM accumulation. Differences in SGR were observed among varieties along the SFD, the maximum SGR from the beginning of SFD to the mid of season was recorded by local variety with $0.097 \mathrm{~g} \mathrm{~d}^{-1}$ but at the period from mid of the SFD to PM the superiority was to $\mathrm{V} 1$ variety by $0.212 \mathrm{~g} \mathrm{~d}^{-1}$ the environmental factors that exceeded the period of seed filling may influenced the accumulating of assimilates and daily SGR, in which the period was much shorter than first season and the rising of temperature especially in the later weeks of the period (appendix, 2). These Results are in accordance to what were found by (Munier-Jolain, et al. 1998; Ehdaie and Waneis, 2010; Sanghera and Thind, 2014). Tabs. 6 and 7, and Figs. 1 and 2 reveals the significant differences among seven varieties in spike Partitioning Coefficient (SPC), in both seasons, there were general declining in DM partitioning to the stem and leaves from the beginning of SFD to the PM for all varieties as well as increasing in spike weight, Figs. 1 and 2, showed maximum SPC recorded in the first season by V1 at week before PM, While in the second season V2 variety was the best in SPC at the PM recording $0.667 \%$. The higher partitioning of assimilates may affected the seed size as a very important factor of yield component which resulted in the highest grain yield production of this variety. Wheat

Tab. 6. Dry matter accumulation partitioned to stem in both seasons

\begin{tabular}{|c|c|c|c|c|c|c|c|c|c|c|}
\hline \multirow{3}{*}{ Varieties } & \multicolumn{10}{|c|}{ Accumulated Dry Matter Partitioned to Stem } \\
\hline & \multicolumn{5}{|c|}{ First Season } & \multicolumn{5}{|c|}{ Second Season } \\
\hline & $14 / 4$ & $24 / 4$ & $5 / 5$ & $15 / 5$ & $25 / 5$ & $14 / 4$ & $24 / 4$ & 5-May & $15 / 5$ & $25 / 5$ \\
\hline V1 & 4.567 & 5.133 & 5.900 & 2.900 & 3.133 & 4.800 & 4.800 & 4.167 & 5.300 & 3.600 \\
\hline $\mathrm{V} 2$ & 3.167 & 5.400 & 5.733 & 3.233 & 3.933 & 4.033 & 4.033 & 6.933 & 3.800 & 0.667 \\
\hline V3 & 3.467 & 3.167 & 2.200 & 1.267 & 2.300 & 4.267 & 4.267 & 4.000 & 3.200 & 1.667 \\
\hline V4 & 3.500 & 6.500 & 3.300 & 2.600 & 2.133 & 3.667 & 3.667 & 4.967 & 4.933 & 3.333 \\
\hline V5 & 6.667 & 6.333 & 5.833 & 3.533 & 3.800 & 6.333 & 6.333 & 5.333 & 4.700 & 3.667 \\
\hline V6 & 5.733 & 4.300 & 5.100 & 2.800 & 2.767 & 3.233 & 3.233 & 5.700 & 3.467 & 1.633 \\
\hline V7 & 4.367 & 5.567 & 3.700 & 1.733 & 1.433 & 4.867 & 4.867 & 7.500 & 4.300 & 3.633 \\
\hline L.S.D & 2.637 & 2.436 & 2.833 & 1.964 & 1.957 & N.S & N.S & 2.259 & 1.747 & 1.521 \\
\hline
\end{tabular}

Tab. 7. Dry matter accumulation partitioned to leaves in both seasons

\begin{tabular}{|c|c|c|c|c|c|c|c|c|c|c|}
\hline \multirow{3}{*}{ Varieties } & \multicolumn{10}{|c|}{ Accumulated Dry Matter Partitioned to Leaves } \\
\hline & \multicolumn{5}{|c|}{ First Season } & \multicolumn{5}{|c|}{ Second Season } \\
\hline & $14 / 4$ & $24 / 4$ & 5-May & $15 / 5$ & $25 / 5$ & $14 / 4$ & $24 / 4$ & 5-May & $15 / 5$ & $25 / 5$ \\
\hline $\mathrm{V} 1$ & & 1.633 & 1.467 & 0.333 & 3.333 & & 1.900 & 1.333 & 1.267 & 0.667 \\
\hline V2 & & 2.067 & 1.333 & 0.633 & 3.667 & & 1.433 & 2.233 & 0.733 & 0.533 \\
\hline V3 & & 1.533 & 0.700 & 0.700 & 3.333 & & 2.767 & 1.300 & 1.033 & 0.900 \\
\hline V4 & & 2.333 & 1.167 & 0.867 & 3.000 & & 1.433 & 1.800 & 1.367 & 0.700 \\
\hline V5 & & 1.967 & 1.233 & 0.767 & 4.000 & & 2.233 & 1.267 & 0.517 & 0.667 \\
\hline V6 & & 2.067 & 1.233 & 0.700 & 3.667 & & 1.567 & 1.800 & 0.800 & 0.500 \\
\hline V7 & & 2.133 & 1.067 & 0.200 & 3.333 & & 2.133 & 3.200 & 1.033 & 0.700 \\
\hline L.S.D & & N.S & N.S & 0.516 & NS & & N.S & 0.964 & NS & NS \\
\hline
\end{tabular}


productivity depends on dry matter accumulation and the alteration in source-sink especially during the seed filling period, significant differences in the SPC among seven varieties may resulted under the differences in photosynthetic efficiency as well as the efficiency converting light energy to dry matter and allocating of accumulated DM to the spike, and the reserve mobilization from wheat plant parts such as stem. Similar results were obtained by (Blum, 1998; Kumar et al., 2006).

Tab. 8 and Annexes 1 and 2, indicate the significant differences between the environmental

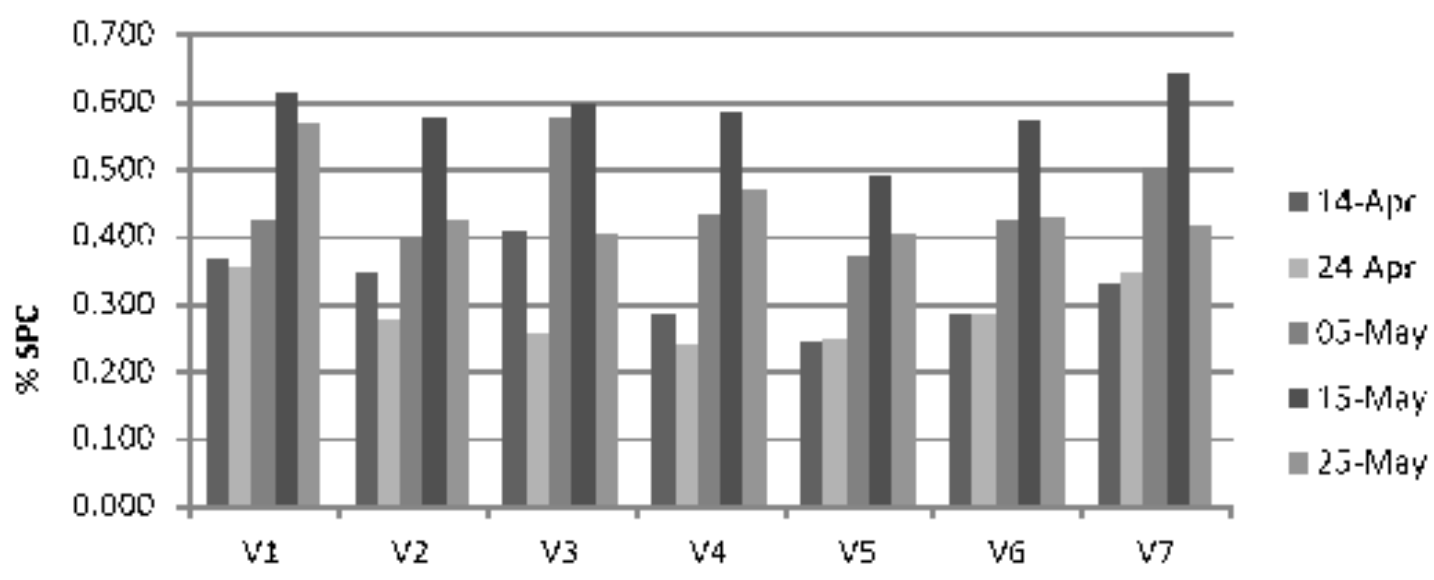

Variętięs

Fig. 1. Spike Partitioning Coefficient at different periods post-Anthesis in the first season

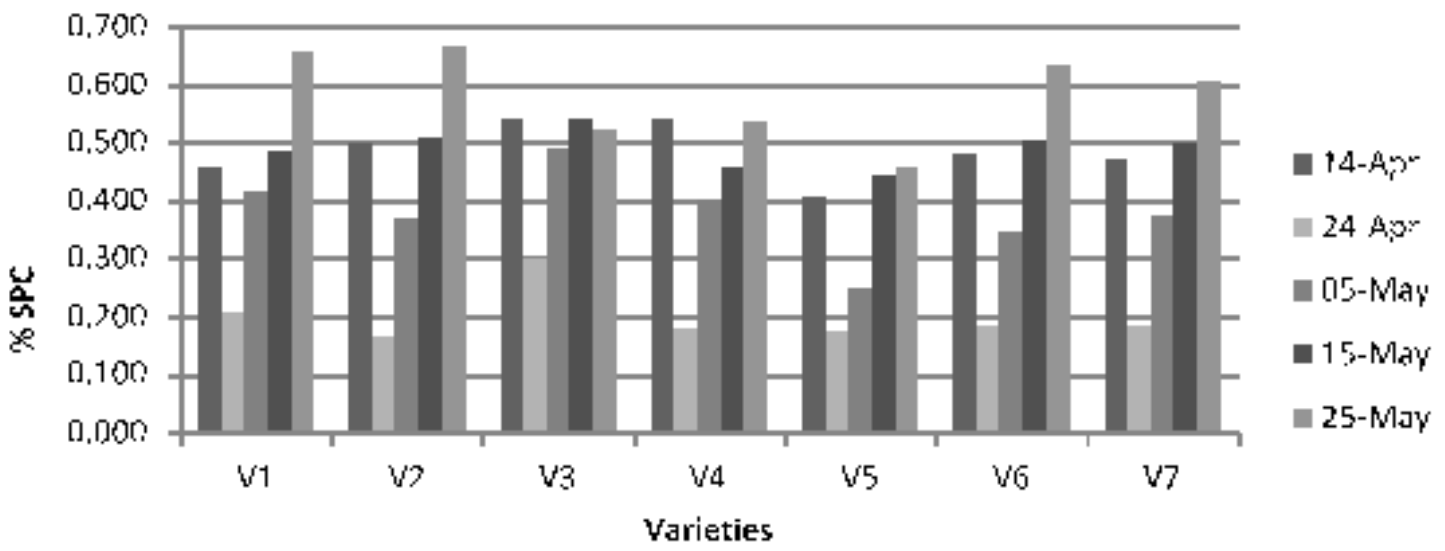

Fig. 2. Spike Partitioning Coefficient at different periods post-Anthesis in the second season

Tab. 8. Effect of years on the accumulated dry matter partitioned to different parts of the plant, leaf,stem and spike

\begin{tabular}{|c|c|c|c|c|c|c|c|c|c|c|c|c|c|c|c|}
\hline \multirow{2}{*}{ Year } & \multicolumn{3}{|c|}{$14 / 4$} & \multicolumn{3}{|c|}{$24 / 4$} & \multicolumn{3}{|c|}{$5 / 5$} & \multicolumn{3}{|c|}{$15 / 5$} & \multicolumn{3}{|c|}{$25 / 5$} \\
\hline & leaf & stem & spike & leaf & stem & spike & leaf & stem & spike & leaf & stem & spike & leaf & stem & spike \\
\hline Y1 & 4.495 & 4.495 & 2.095 & 1.962 & 5.200 & 2.904 & 1.171 & 4.538 & 4.442 & 0.600 & 2.561 & 4.338 & 3.524 & 2.785 & 5.142 \\
\hline $\mathrm{Y} 2$ & 3.299 & 3.299 & 4.142 & 1.923 & 4.457 & 1.633 & 1.847 & 2.259 & 4.495 & 0.965 & 4.243 & 4.981 & 0.666 & 1.521 & 4.571 \\
\hline LSD & NS & NS & 0.783 & NS & NS & 0.768 & 0.237 & 1.449 & NS & NS & 0.735 & NS & 1.084 & NS & NS \\
\hline
\end{tabular}


ANNEXES

Annex 1. Meterological data for the period April 16 - May 31- 2013

\begin{tabular}{|c|c|c|c|c|c|c|c|c|}
\hline Date & Rate & $\begin{array}{l}\text { Windvane } \\
\text { Degree }\end{array}$ & Humidity & $\begin{array}{c}\text { Air Temp } \\
\text { C }\end{array}$ & $\begin{array}{r}\text { Energy } \\
\mathrm{m}^{-2}\end{array}$ & $\begin{array}{c}\text { Pressure } \\
\mathrm{mb}\end{array}$ & $\begin{array}{l}\text { Wind speed } \\
\text { ms-1 }\end{array}$ & $\begin{array}{c}\text { Rainfall } \\
\mathrm{mm}\end{array}$ \\
\hline \multirow{3}{*}{$16 / 4-23 / 4$} & Average & 205.3 & 38.9 & 15.8 & 214.6 & 823 & 1.4 & 520.8 \\
\hline & Max. & 355 & 95 & 24.4 & 1034.3 & 850.9 & 4.7 & 528.6 \\
\hline & Min. & 0.1 & 15.4 & 7.5 & 0 & 814.3 & 0 & 518.6 \\
\hline \multirow{3}{*}{$24 / 4-30 / 4$} & Average & 180.9 & 18.3 & 21.2 & 332.4 & 829.9 & 0.9 & 528.6 \\
\hline & Max. & 354.4 & 82.4 & 31.8 & 1060.9 & 850.4 & 3.9 & 528.6 \\
\hline & Min. & 0.1 & 12.7 & 8.4 & 0 & 822.6 & 0 & 528.6 \\
\hline \multirow{3}{*}{$1 / 5-7 / 5$} & Average & 194.9 & 32.5 & 22.1 & 245.3 & 826.8 & 1 & 531.8 \\
\hline & Max. & 351.7 & 95 & 30.5 & 1056.5 & 854.3 & 4.3 & 548 \\
\hline & Min. & 0.1 & 14.8 & 14.4 & 0 & 818.7 & 0 & 528.6 \\
\hline \multirow{3}{*}{$8 / 5-15 / 5$} & Average & 181.9 & 49.5 & 21.1 & 231.5 & 826.3 & 1.3 & 557.3 \\
\hline & Max. & 347.1 & 95 & 33.7 & 1074.5 & 850.9 & 5.3 & 571.8 \\
\hline & Min. & 0.1 & 10.0 & 12.4 & 0 & 817.7 & 0 & 548.2 \\
\hline \multirow{3}{*}{$16 / 5-23 / 5$} & Average & 197 & 28.8 & 21.8 & 291.6 & 828 & 1.3 & 572.4 \\
\hline & Max. & 354.5 & 75.5 & 32.2 & 1123.1 & 869.4 & 4.6 & 572.4 \\
\hline & Min. & 0.1 & 11.3 & 12 & 0 & 818.2 & 0 & 572.4 \\
\hline \multirow{3}{*}{$24 / 5-31 / 5$} & Average & 195.3 & 14.8 & 27.1 & 333.2 & 846.6 & 1.3 & 572.4 \\
\hline & Max. & 355.1 & 35.2 & 37.5 & 1069.8 & 875.3 & 5.4 & 572.4 \\
\hline & Min. & 0.1 & 10.2 & 16.9 & 0 & 817.7 & 0 & 572.4 \\
\hline
\end{tabular}

Annex 2. Meterological data for the period April 16 - May 31- 2014

\begin{tabular}{|c|c|c|c|c|c|c|c|c|}
\hline Date & Rate & $\begin{array}{l}\text { Windvane } \\
\text { Degree }\end{array}$ & $\begin{array}{l}\text { Humidity } \\
\% \mathrm{RH}\end{array}$ & $\begin{array}{c}\text { Air Temp. } \\
\text { C }\end{array}$ & $\begin{array}{r}\text { Energy } \\
\mathrm{m}^{-2}\end{array}$ & $\begin{array}{c}\text { Pressure } \\
\mathrm{mb}\end{array}$ & $\begin{array}{l}\text { Wind speed } \\
\text { ms-1 }\end{array}$ & $\begin{array}{c}\text { Rainfall } \\
\mathrm{mm}\end{array}$ \\
\hline \multirow{3}{*}{$16 / 4-23 / 4$} & Average & 109.7 & 41 & 20 & 260.6 & 838.9 & 1.2 & 601.2 \\
\hline & Max. & 347.7 & 80.5 & 29.6 & 1012.1 & 872.4 & 3.8 & 602.2 \\
\hline & Min. & 0.1 & 10.7 & 11.5 & 0 & 819.1 & 0 & 600.6 \\
\hline \multirow{3}{*}{$24 / 4-30 / 4$} & Average & 221.1 & 41.8 & 21.6 & 283.9 & 838.2 & 1.1 & 607.2 \\
\hline & Max. & 353.1 & 93.5 & 31.6 & 1060.9 & 866 & 4.3 & 617 \\
\hline & Min. & 0 & 11.4 & 12.5 & 0 & 819.1 & 0 & 602.2 \\
\hline \multirow{3}{*}{$1 / 5-7 / 5$} & Average & 224.1 & 22.2 & 23.1 & 320.1 & 834.1 & 1 & 617 \\
\hline & Max. & 354.1 & 50.3 & 35.1 & 1096.4 & 866 & 4.2 & 617 \\
\hline & Min. & 0 & 9.0 & 13 & 0 & 818.7 & 0 & 617 \\
\hline \multirow{3}{*}{$8 / 5-15 / 5$} & Average & 236.5 & 25.2 & 24 & 281.7 & 835.4 & 1.1 & 620.8 \\
\hline & Max. & 236.5 & 71.4 & 34.1 & 1074.2 & 880.2 & 3.9 & 627.2 \\
\hline & Min. & 236.5 & 9.1 & 14.3 & 0 & 817.2 & 0 & 617 \\
\hline \multirow{3}{*}{$16 / 5-23 / 5$} & Average & 236.5 & 13.9 & 24.2 & 276.2 & 837.9 & 1 & 627.3 \\
\hline & Max. & 236.5 & 56.1 & 34.5 & 1096.4 & 875.3 & 4.5 & 629 \\
\hline & Min. & 236.5 & 10.2 & 14 & 0 & 818.2 & 0 & 627.2 \\
\hline \multirow{3}{*}{$24 / 5-31 / 5$} & Average & 236.5 & 12.6 & 27.2 & 311.1 & 833.2 & 1.1 & 631.8 \\
\hline & Max. & 236.5 & 48.1 & 38.1 & 1087.5 & 868.9 & 4.2 & 634 \\
\hline & Min. & 236.5 & 10.0 & 17 & 0 & 816.7 & 0 & 629 \\
\hline
\end{tabular}


and climatic factors of the two years on the rate of dry matter accumulating and the partitioning to different parts leaf, stem, and spike along the period of seed filling SFD. While the second year exceeded the first in more partitioning of assimilates and photosynthesis to spike by $4.142 \mathrm{~g}$ at the beginning of SFD at April14 ${ }^{\text {th }}$, there was exceeding of first year in partitioning to spike at April24 $4^{\text {th }}$, by $2.904 \mathrm{~g}$. There were no significant differences between the two years in the mid of the period of SF and also at May $15^{\text {th }}$, and May 25, however there were significant differences between the two years in partitioning to leaf and stem at May $5^{\text {th }}$, May $15^{\text {th }}$, and May $25^{\text {th }}$. In which the first year exceeded the second in partitioning to stem and leaf at May $5^{\text {th }}$, and May $25^{\text {th }}$ by (4.538g and 3.524)g, respectively. The superiority of second year was at May $5^{\text {th }}$ and May $15^{\text {th }}$ in partitioning to stem and leaf by $(1.847$ and 4.243)g, respectively. The results agree with some other researches (Egli, 2004; Jaradat, 2009; Liu, 2010.)

\section{CONCLUSION}

Variation was noticed in the length of the period of seed filling for all varieties in both seasons, but the SFP of the second season was much shorter than the first. The environmental factors that exceeded during the period of seed filling of the second season may had influenced the accumulating of assimilates and daily SGR, especially temperature rising in the later weeks of the period. Dry matter accumulation and its partitioning were influenced according to the length of growth stages pre and post flowering much more than the length of SFD which genetically regulated. Climatic factors especially temperature and $\mathrm{RH} \%$ play a great role in the rate of dry matter accumulation and its partitioning.

\section{REFERENCES}

1. Blum A (1998). Improving wheat grain filling under stress by stem reserve mobilization. Euphytica, 100 (2):77 - 83.

2. Egli DI (2004). Seed- Fill Duration and Yield of Grain Crops. Advances in Agronomy 83:283-295

3. Ehdaie B, Waines JG (2001). Sowing date and nitrogen rate effects ondry matter and nitrogen partitioning in bread and durum wheat. Field crops research 73(1):47-61

4. FAO (2015). Document Repository: Use of FAO's Technical Cooperation Programme to help Small Island Developing States adapt to climate change. FAO Conference. $39^{\text {th }}$ Session Rome, 6 - 13 June 2015.

5. Jaradat A (2009). Modeling biomass allocation and grain yield in bread and durum wheat under abioticstress. Australian Journal of Crop Science 3(5):237-248.

6. Kumar R, Sarawagi AK, Ramos C, Amarante ST, Ismail AM, Wade LJ (2006). Partitioning of dry matter during drought stress in rainfed lowland rice. Field Crops Res 98:1-11.

7. Liu YE, Wang X, Yang X, Wang J (2010). Contributions of climatic and to crop varietal changes to crop production in the north China plain, since 1980s. Global change Biology 16:2287-2299.

8. Meng Q Yue S, Chen X, Cui Z, Ye Y, Ma W, Tong Y, Zhang $F$ (2013). Understanding Dry Matter and Nitrogen Accumulation with Time-Course for High-Yielding Wheat Production in China. PLoS One 8(7): e68783.

9. Munier-Jolain NG, Munier-Jolain NM, Roche R, Ney B, Duthion C (1998) Effect of photo assimilate availability on seed growth rate. Journal of Experimental Botany, 49(329):1963-1969.

10. Nicolas ME, Gleadow RM, Dalling MJ (1984). Effects of Drought and High Temperature on Grain Growth in Wheat. Aust. J. Plant Physiol., 11(6):553-566

11. SangheraAK,ThindSK(2014).DryMatterAccumulationand Partitioning in Wheat Genotypes as Affected by Sowing Date Mediated Heat Stress. IJST 3(8):3-6

12. Salazar-Gutierrez MR, Johnsonb J, Chaves-Cordobaa B, Hoogenboom G (2013). Relationship of base temperature to development of winter wheat. International Journal of Plant Production 7 (4):741-742 